\title{
The Idea of Mass Customization in the Door Industry Using the Example of the Company Porta KMI Poland
}

\author{
Marta Pędzik ${ }^{1}$, Joanna Bednarz ${ }^{2}$ (D) Zdzisław Kwidziński ${ }^{3}$, Tomasz Rogoziński ${ }^{1} * *^{\circledR}$ and \\ Jerzy Smardzewski ${ }^{1}$ iD \\ 1 Department of Furniture Design, Faculty of Wood Technology, Poznań University of Life Sciences, ul. Wojska \\ Polskiego 38-42, 60-637 Poznań, Poland; marta.montenegro95@gmail.com (M.P.); \\ jsmardzewski@up.poznan.pl (J.S.) \\ 2 Department of International Business, Faculty of Economics, University of Gdansk, ul. Armii Krajowej \\ 119/121, 81-824 Sopot, Poland; joanna.bednarz@ug.edu.pl \\ 3 Porta KMI Poland, ul. Szkolna 54, 84-239 Bolszewo, Poland; Zdzislaw_Kwidzinski@porta.com.pl \\ * Correspondence: tomasz.rogozinski@up.poznan.pl
}

Received: 1 April 2020; Accepted: 5 May 2020; Published: 7 May 2020

check for updates

\begin{abstract}
The paper concerns the importance of the trend of mass customization in building the competitive advantage of companies in the door joinery sector in Poland. Its purpose is an attempt at assessing the effects of mass customization carried out on a newly designed TechnoPORTA technological line for automated door production on the basis of an analysis of selected technical and economic indexes related to manufacturing costs. The basis for the calculation of these indexes was the value of material and labor costs and the projected production value in relation to eleven selected types of industrial doors. Based on the analysis of technical and economic indexes, it can be concluded that the introduction of the concept of mass customization will reduce gross costs of manufactured products which, with the assumed level of sales, will translate into annual profit. The results obtained allow for optimistic conclusions about the possibility of building the long-term competitive advantage of door manufacturers.
\end{abstract}

Keywords: mass customization; door frame industry; sustainable business model; production cost

\section{Introduction}

The external environment of contemporary door manufacturing companies is characterized by enormous complexity and variability. Entrepreneurs must, on the one hand, pay close attention to the increasing activity of their competitors, as well as to buyers whose needs, preferences and expectations change with the emerging trends and fleeting fashions. In order to meet these challenges, companies must build their competitive advantage, especially in the long term. The idea of competitive advantage is to provide a company with superior position or to allow a company to be seen differently compared to its competitors [1]. This requires that it possesses resources including financial, physical, human, and organizational assets [2] as well as superior skills understood as distinctive capabilities of personnel that set them apart from the staff of competing firms [3,4]. Taken together, these factors represent the ability of a business to do more or do better (or both) than its competitors, especially to develop, manufacture, and deliver products or services to its customers. They may lead to higher precision or reliability in the finished product [3].

The continually evolving consumer market transforms the notion of pursuit of customers, and the traditional methods become insufficient. The solution to this problem may be to make the offer more attractive and individualized in relation to the preferences and needs of a specific customer or target group. This requires maintaining constant, direct contact with a particular customer and 
involving them in the door design process in order to bring values that are important to them into the design. A product configurator can be a tool that significantly facilitates the transfer of information between customers and the manufacturer. It allows the creation of the expected product from a pool of possible modifications [5]. It is also important to refer to the information obtained, as well as to apply appropriate communication techniques and increase the flexibility of the production technology at the lowest possible unit costs [6-8]. The logistic issue is also significant, and the system developed must be characterized by dynamic deliveries. Obtaining customer satisfaction arising from the combination of these factors may result in renewed willingness to buy the products of a given company and publicizing its good reputation among new potential buyers. It is small and medium enterprises, often filling individual and one-off orders, that will have an advantage in this respect. However, advanced IT and technological development solutions enable larger companies to be much more flexible in the production process and to modify the standard product in order to alter its properties and strengthen those of greater importance to the customers.

The article was prepared based on data provided by Porta KMI Poland-the leading company in the door industry in Poland. For 25 years, this company has been producing doors based on the highest standards and current trends in design, as well as constantly monitoring the development of technology. An example of the development strategy was the introduction of the concept of mass customization on the innovative TechnoPORTA line. Porta KMI Poland implemented this project under the Intelligent Development Operational Program 2014-2020. The purpose of the activities was to demonstrate a pilot line enabling the production of industrial doors with significantly increased dimensions and weight. In particular, this concerned external doors with dimensions of $1500 \times 3000 \times$ $35 \div 90 \mathrm{~mm}$, weighing up to $200 \mathrm{~kg}$, and the ability to ensure the highest hygiene standards, including compliance with the medical directive MDD 93/42/EEC. The project assumes that door production will take place in the most automated way, guaranteeing consistent and high-quality products. As a result of project implementation, the efficiency of the developed pilot line was achieved at the level of 800 doors per production shift. The demand for electricity in the production cycle for industrial doors has been reduced by approximately $15 \%$. The implemented pilot line carries out production oriented to the individual needs of end users. This is manifested in the variability of door dimensions defined by the customer, automatic selection of door edge processing technology, as well as mortises and holes for individually selected locks and handles. The pilot line consists of five modules. Each of the components of the line carries out different tasks in the production cycle. The whole line is controlled by the original, innovative, and proprietary "translator" IT system, which not only selects the right technological operations but optimizes the time of production cycles. The customer of the door is, therefore, sure that they are made in accordance with his order and precisely on time.

The aim of the paper is an attempt to assess the effects of mass customization on a newly designed TechnoPORTA technological line for automated door production on the basis of an analysis of selected technical and economic indexes related to manufacturing costs.

The study could be considered as a framework to identify ways to achieve competitive advantage of companies in the door sector. Managers of these companies should be prepared for constant changes regarding the preferences and needs reported by customers to prepare their products in an appropriate way.

The paper consists of seven parts. The first three parts develop the theoretical background and literature review, including mass customization as well as characteristic of the door sector in Poland. Next sections contain the methodology and illustrate the results. The paper finishes with discussion, conclusions, and practical implications and limitations of the study.

\section{The Idea of Mass Customization}

The idea of mass customization (MC) was put forth by Davis more than 30 years ago. For him, MC takes place when the same large number of customers can be reached as in mass markets of the industrial economy, and are simultaneously treated individually as in the customized markets 
of pre-industrial economies [9]. While reviewing the literature, one can notice different definition approaches proposed by researchers. They underline various critical elements of MC in their statements. Emphasizing the level of price, Pine [10] defined MC as providing tremendous variety and individual customization, at prices comparable to those of standard goods and services to enable the production of products and services with enough variety and customization so that nearly everyone finds exactly what they want. Pine [11] referred to the term as the "solution space" and underlined that a successful mass customization system is characterized by stable but still flexible and responsive processes that provide a dynamic flow of products. Tseng and Jiao [6] highlighted technological conditions. For them, MC corresponds to "technologies and systems to deliver goods and services that meet individual customers' needs with near mass production efficiency". Piller [12] stressed customer co-design in the process of offering products and services, which meet the needs of each individual customer with regard to certain product features. In the article, MS is understood in accordance with the definitional proposal of Ferguson et al. [13] — "a product development approach that allows for the creation of goods that minimize the trade-off between the ideal product and the available product by fulfilling the needs and preferences of individuals functionally, emotionally, and anthropometrically, while maintaining system costs comparable to mass produced products".

The implementation and development of the concept of MC is possible because of three main reasons pinpointed by Squire et al. [14]: (1) the collapse in mass markets and "one size fits all" products, (2) a visible process of shortening product life cycles, and (3) new production and information technologies that enable firms to produce to a customer's specification at the low cost and high speed of standardized offerings.

Nowadays, companies are able to focus on MC because of three critical capabilities as proposed by Zipkin [15]: (1) elicitation (a mechanism for interacting with the customer and obtaining specific information), (2) flexible production process (production technology, methods, and knowledge that manufacture the product in accordance with the available data), and (3) logistics (subsequent processing steps and direct-to-customer distribution that are able to maintain the identity of each item and to deliver each individual product to the right person).

Nowadays manufacturers are encouraged to implement mass customization by observing buyer behaviour and preferences. They should take into consideration one-to-one marketing which represents an extreme form of segmentation, with a target segment of size one [16]. Moreover companies should perceive consumers as prosumers. According to Toffler [17], prosumers are individuals who act as both producer and consumer. They take an active part in the development and management of products and services (co-creation of new products based on personal preferences and values, testing them, improving their quality), commercialization of products and services (advising in communication, distribution and pricing policies and instruments), delivery of products and services (improving processes), and management of customer services [18,19]. It seems that MC can be treated as a key instrument in building relations between producer and customers. It is the appropriate way to increase customer satisfaction and thus hence customer retention [20]. Then comes the increase in customer loyalty. Once the customer has successfully purchased an individual item, the knowledge acquired by the manufacturer during the product configuration represents a considerable barrier against switching the supplier [21].

Analyzing changes in consumer behaviour, it can be concluded that customization is one of many noticeable megatrends. Consumers expect to be offered industrially-produced goods tailored to their individual, personalized preferences [22], thus upping customer satisfaction levels and perceived product value [23]. The authors of the Connected Shoppers Report [24] pinpoint that more than half of shoppers are drawn to brands and retailers that offer limited-edition or customized products $(54 \%)$. These preferences are even stronger among younger generations $(72 \%)$.

Similarly, Lihra et al. [25] and Dimkov [26] stress in their work that customization should be treated as a competitive strategy in the market of the door sector, as the key to success, and not a temporary trend, as Schuler and Buehlmann predict in their work [27]. They say that as early as 2035, 
the share of customized products in mass production on the American market will constitute $50 \%$ of that of standard products, and the trend will continue to grow until 2050.

\section{Specifics of Mass Customization in the Door Industry in Poland}

The total door production in Poland in 2019 is estimated at around 9.3-9.4 million pieces. It has not changed compared to the previous year. The company Porta KMI Poland produced about 1 million doors, which resulted in revenue from sales of PLN 500 million. Thanks to this, the overall share of this company in the Polish door market is estimated at around $13 \%-16 \%$. In the sector of industrial doors, the share of Porta KMI Poland is higher and reaches $25 \%-30 \%$.

In the second quarter of 2019, the results of industrial production and retail sales of door manufacturing companies in Poland were at the right level. Nevertheless, a decline in sales was noted, which was due to, among other things, visibly faster growth of the costs of labor, outsourced services, and energy spending. As a result, despite the increase in the return on turnover, the return-on-sales ratio decreased. Demand assessments in third quarter of 2019 suggest that the result may be worse than in the previous period. Also, the companies' domestic demand projections for the fourth quarter have decreased and remain close to the long-term average. According to the representatives of Polish companies, the most important threat to the situation of exporters and importers is the downturn in the German economy. Changes in GDP (gross domestic product) in Germany are presented in Figure 1. Germany's real GDP growth rebounded tangibly from a near-recession in 2018 to $0.4 \%$ in the first quarter of 2019. The projection is to increase by $0.5 \%$ in 2019 and by $1.4 \%$ in 2020 [28].

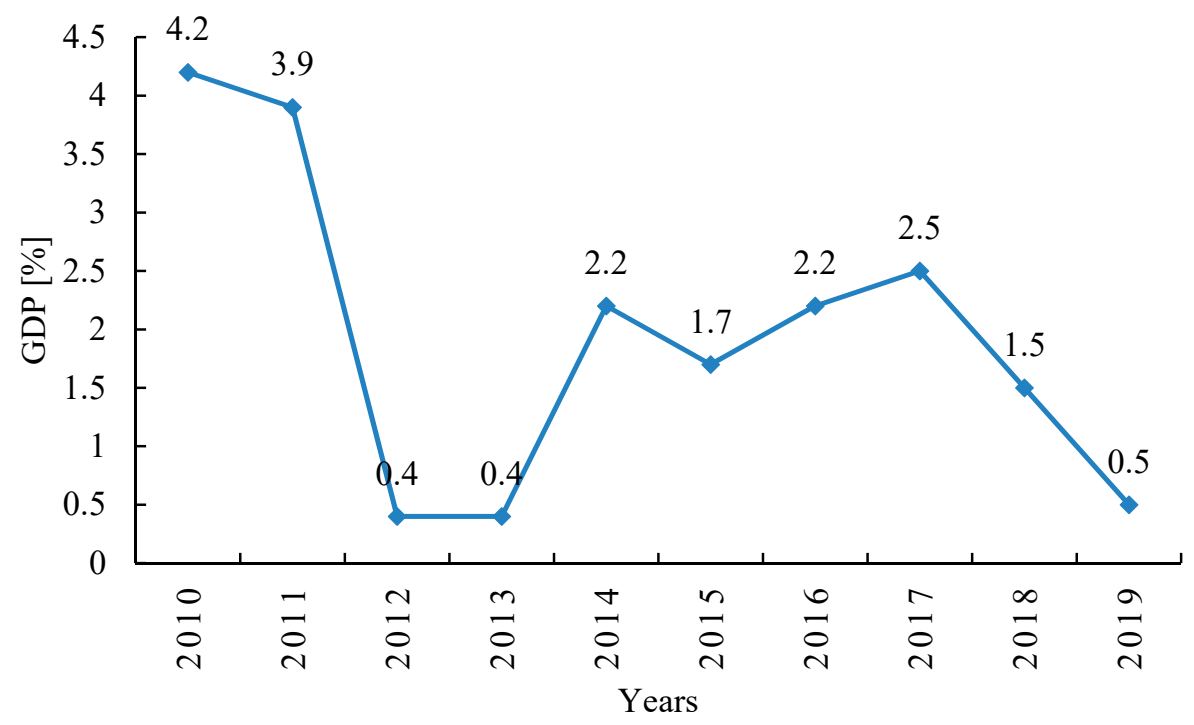

Figure 1. Real GDP growth rate in Germany 2010-2019 (\%). Source: Eurostat.

For years now, manufacturers in the door industry (global market) have been conducting research on the introduction of the concept of mass customization into their plants, which is described in numerous case studies in the works of, among others, Moreira et al. [29], Shults [30], Suzić et al. [31], Suzić et al. [32]. This is a difficult task because, in the industry, the restrictions to carry out mass customization result from technical standards specifying the requirements in terms of strength, burglary resistance, sound absorption or other factors, with particular emphasis on doors intended for public buildings. In residential buildings, the zone that can be modified is much wider, and parameters such as the type of finish or dimensions can be changed depending on the taste and purpose of the product. However, it is inevitable that significant changes will be made to both the technology and the company's production process.

Indoor manufacturing plants and complex production programs are usually in place, resulting from an extensive range of products that vary in their form, purpose, or dimensions. The variety of 
elements makes it difficult to schedule production, and therefore, in order for the process of mass customization to be possible, it is necessary to focus on the greatest possible standardization of elements, obtaining their structural similarity usually on the basis of a modular and/or package structure. It is important to strictly define the extent to which customization will be carried out and to simplify the flow of materials by analyzing their movement during production, which in combination with the grouping technology will allow the achievement of positive effects. The grouping technology consists in combining elements of which the product is composed, based on their similarities, and creating groups of machines so that the elements which are subject to the same technological operations are in one group. On this basis, the technological sequence is established so that possibly subsequent operations in a given group are carried out simultaneously without waiting for others [31,33].

In order to assess the changes obtained in quantities characterizing the production process, appropriately adjusted technical and economic indexes should be used, which would reflect the plant's efficiency to the greatest extent possible. In turn, the analysis of these indexes at the innovation design stage in the form of implementation of the concept of mass customization could be a decisive aspect of its introduction into the production process. The combination of these factors and the determination of stock levels is intended to allow the costs of products subject to the modification being maintained at a level similar to or lower than their counterparts prior to the introduction of the innovation, and the control of production results in terms of quantity (selected indexes). In practice, the selection of such indexes is extremely difficult.

It is worth adding that 2019 saw a slowdown in sales of products with high customization potential, such as advanced technical door leaves: acoustic, burglar-proof, and door leaves for passive buildings. The drop in sales of these products was noticeable in the period of January to October 2019 compared to the same period of the previous year. It was also noted that the previously predicted increase in inquiries about the production of technical door leaves in connection with the growing trend of customization on the market did not materialize. This thesis is also confirmed by observations of the largest suppliers dedicated to the accessory and laminate industry. Therefore, a significant doubt arose with regard to the production and further development of customization of these products.

\section{Research Methodology}

The basis for the calculation of selected technical and economic indexes related to manufacturing costs were the values of material and labor costs and the projected production value in relation to eleven selected types of technical doors.

Based on costs incurred by the production plant, an analysis was carried out of the effectiveness of innovation consisting in launching the TechnoPORTA smart, customized technological line for automated door production. Eleven types of doors manufactured on this line and door leaves offered by the company were taken into account. Table 1 shows the characteristic detail of each door type in isometric view, including the minimum batch size and a list of basic materials. The numbering assigned to each door type in the table corresponds to the numbering in the successive figures.

Table 1. Overview of basic materials for door production on the TechnoPORTA line.

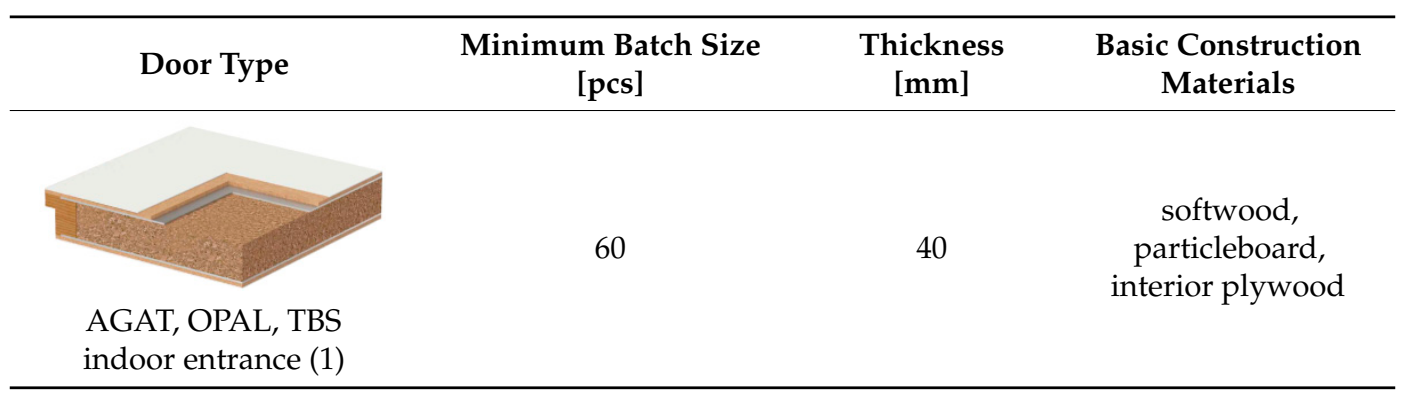


Table 1. Cont.

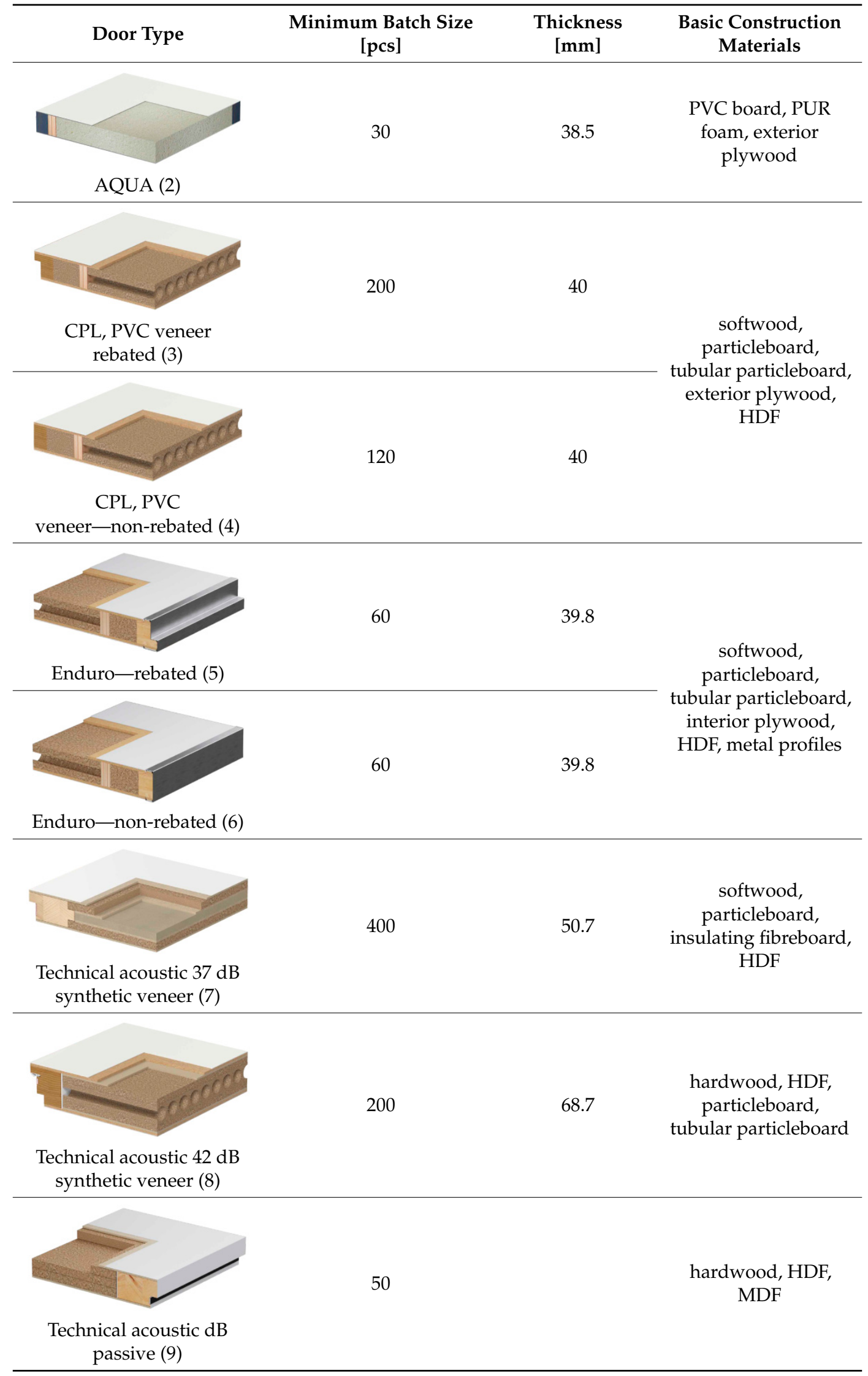


Table 1. Cont.

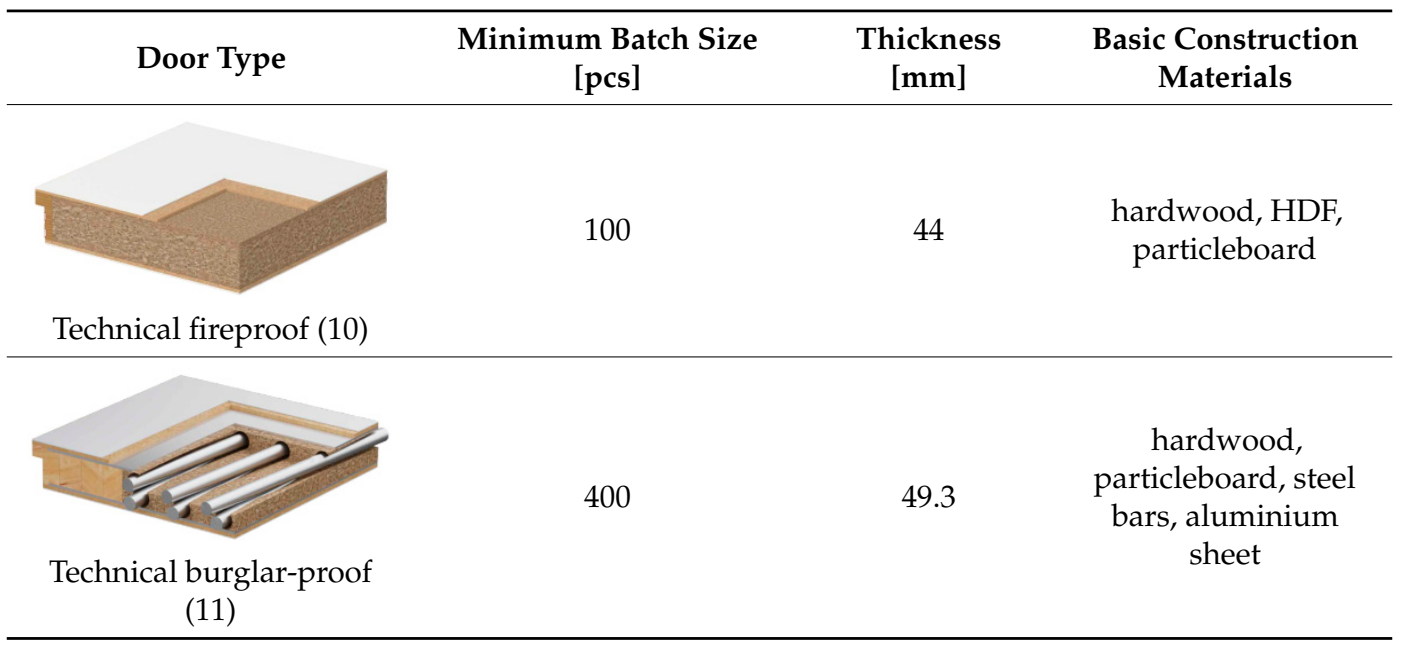

The main technical and economic index taken into account in the analysis is the unit technical production cost (TPC). It is the sum of the unit material cost (UMC) and the unit cost of labour (UCL). The unit material cost for individual door types has not changed due to the implementation of the concept of customization using the TechnoPORTA line. This type of cost is influenced by door materials used in the production and dimensions of the door, especially the thickness of door leaves. Therefore, the expected economic effects in the form of a reduction of the TPC result only from a reduction of the UCL due to the implementation of innovations. The unit saving is therefore the difference $(\triangle T P C)$ between the values of the TPC before and after the start of production on the TechnoPORTA line. Additionally, the decision has been made to calculate the savings ratio (SR):

$$
\mathrm{SR}=\frac{\Delta \mathrm{TPC}}{\mathrm{TPC}}
$$

where TPC is the unit technical cost of manufacturing the leaves before the innovation has been introduced.

The company's projections until 2023 foresee a significant increase in sales of the entire product range included in the analysis. A decision was made, therefore, to calculate the total cost reduction (CR) for door production taking into account these projections. This reduction will represent an annual saving resulting from the reduction of the UCL, and thus the TPC for the door types analyzed:

$$
\mathrm{CR}=\sum_{\mathrm{i}=1}^{11}\left(\mathrm{n}_{\mathrm{i}} \times \Delta \mathrm{TPC}_{\mathrm{i}}\right)
$$

where $\mathrm{i}$ is the door type, $\mathrm{n}_{\mathrm{i}}$ is the projected production (pcs/year), and $\triangle T P C$ is the difference between the values of the TPC before and after the innovation (PLN/pc).

\section{Results}

The unit material cost both before and after the introduction of technological innovation reached the values presented in Figure 2. 


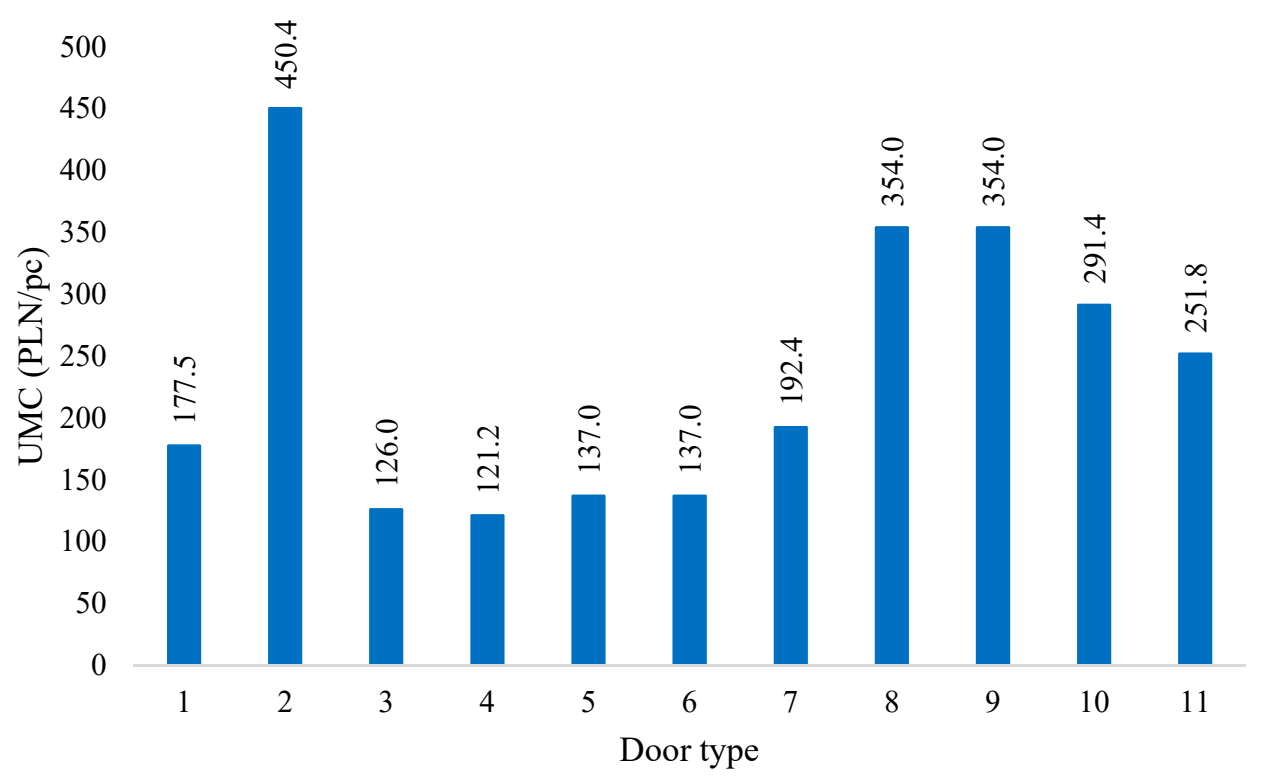

Figure 2. Unit material cost (UMC) values of all door types.

The UMC value has not changed after the introduction of the concept of mass customization, which means that it has had no direct impact on this part of the TPC. The highest unit material cost was for door type 2; i.e., Aqua, which may result from its special construction using relatively expensive materials (exterior plywood, PVC frames, and polyurethane foam), thanks to which such a door becomes resistant to moisture. The lowest material costs were achieved by the non-rebated door and door with CPL and PVC veneer. These are traditional doors, simple in construction, with frames made of glued pine or MDF and filled with extruded particleboard or honeycomb paper.

The UCL values before and after the launch of the TechnoPORTA smart, the customized technological line for automated door production, are shown in Figure 3.

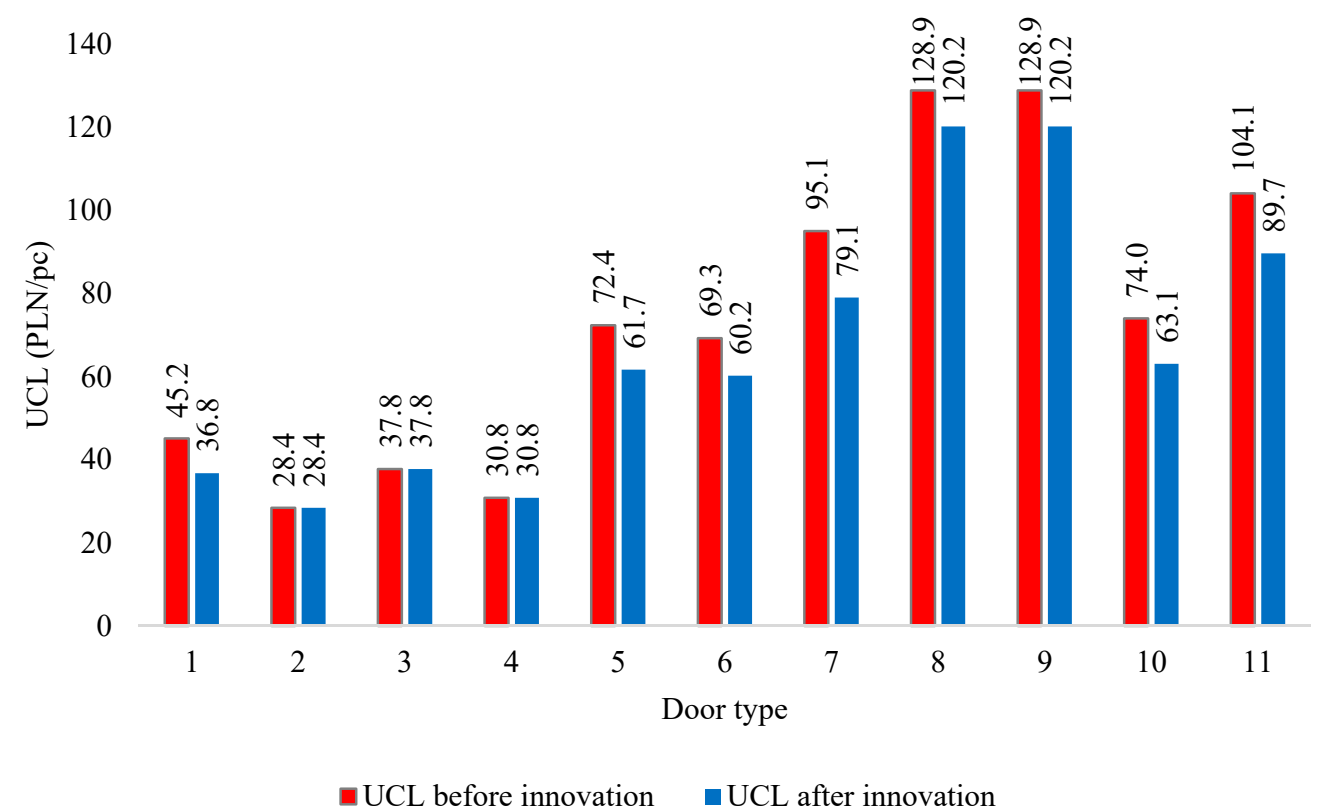

Figure 3. Unit labor cost (UCL) values before and after innovation.

The largest unit labor costs both before and after the introduction of the innovation were for type 8 and 9 doors; i.e., $42 \mathrm{~dB}$ technical acoustic doors, whereas the OPAL, AGAT, TBS-type 1 doors had the lowest UCL. After starting the customization line, the UCL values for door types 2, 3, 4 have not 
changed. In none of the cases analyzed has the cost after the innovation increased, which means that the expected results have been provided.

The calculated unit TPC saving before and after the start of production on the TechnoPORTA line is shown in Figure 4.

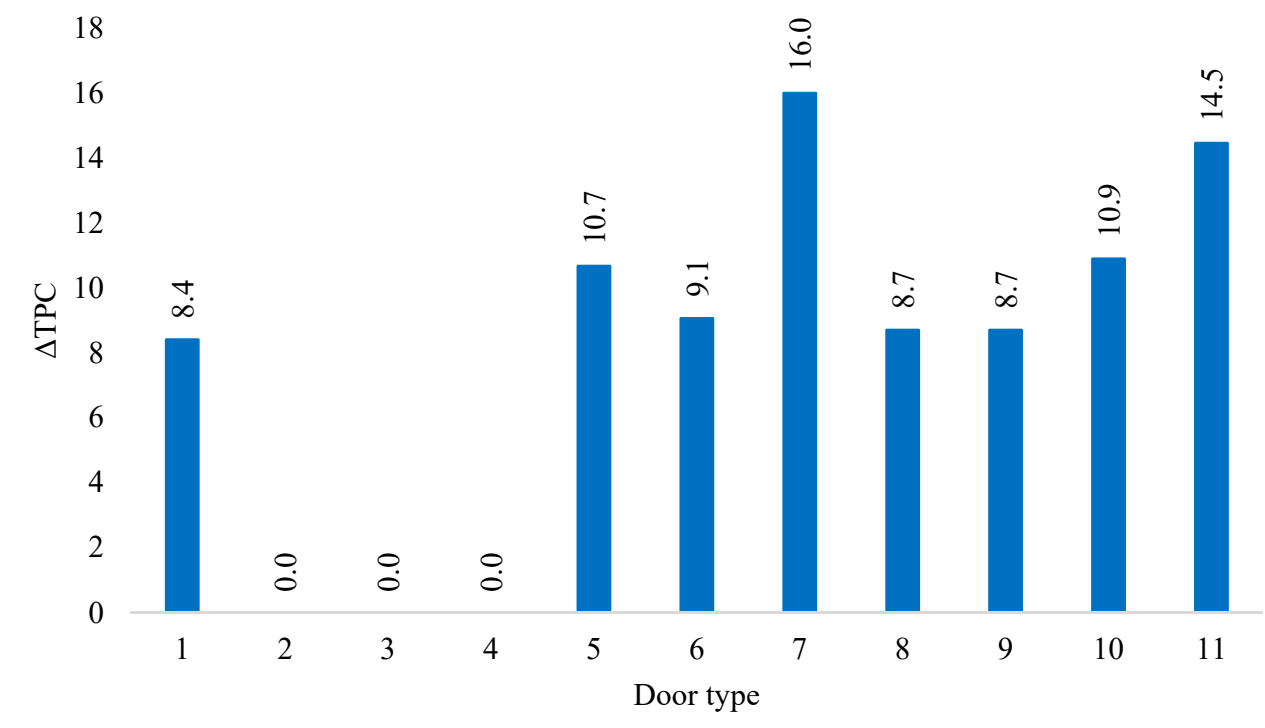

Figure 4. Technical production cost (TPC) difference for all door types.

As the UMC index has a fixed value for each door type both before and after the innovation, only the UCL index affects the TPC. The biggest absolute change of the TPC has been observed for type 7 doors ( $37 \mathrm{~dB}$ technical acoustic with synthetic veneer) and type 11—burglar-proof. However, no changes in labor costs have been observed for door types $2-4$, which results in a constant value of the UCL affecting the TPC.

The percentage decrease of the TPC in relation to the initial level before the innovation is presented in Figure 5.

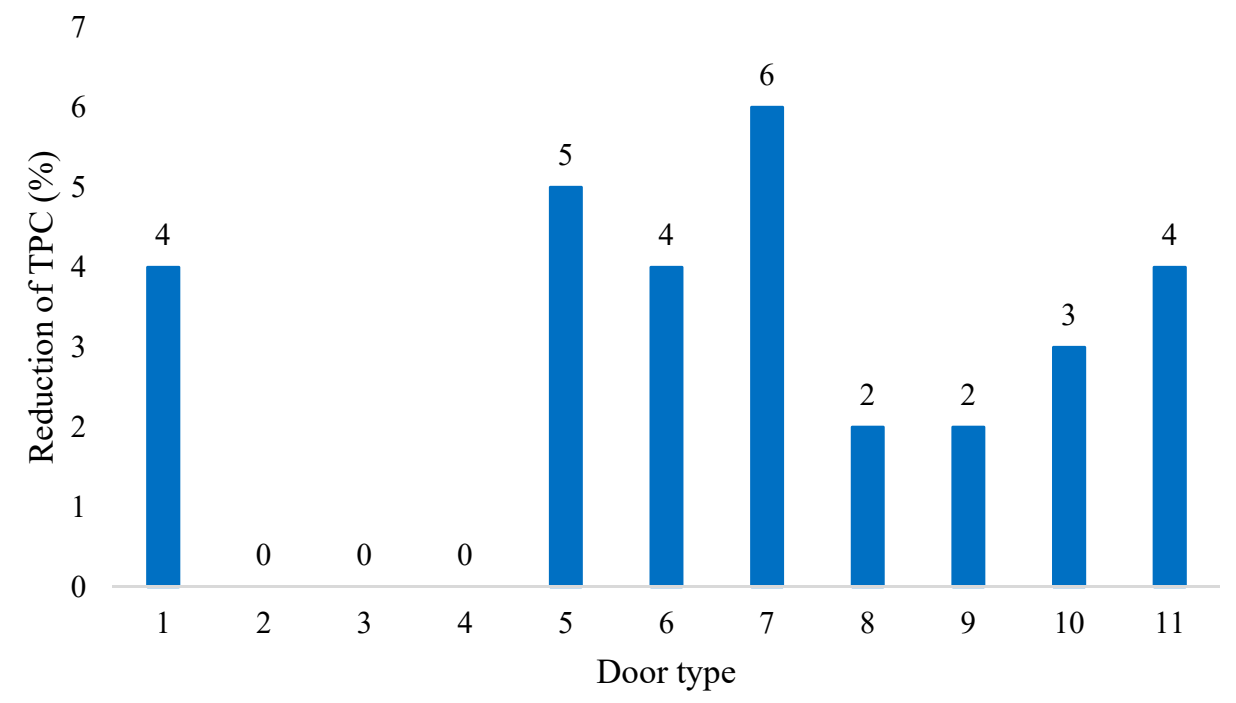

Figure 5. TPC difference for all door types.

The percentage savings resulting from the reduction in the TPC are not only due to the absolute values of $\triangle T P C$. In principle, they are also affected by the UMC as it has a significant impact on the total TPC value. Therefore, the highest percentage reduction of the TPC was found for door types 7 
and 5 , of which door type 5 did not have the highest value of the difference between the technological cost before and after the innovation, consisting of launching the TechnoPORTA line.

Forecasts of the volume of sales of door leaves and the expected reduction of related costs in 2020 are presented in Table 2, while the projected percentage increase of door sales after the introduction of the innovation and savings related to the reduction of the cost of the UCL are shown in Figures 6 and 7.

Table 2. Overview of basic materials for door production on the TechnoPORTA line.

\begin{tabular}{ccc}
\hline Door Type & $\begin{array}{c}\text { Projected Sales } \\
\text { (pcs/year) }\end{array}$ & $\begin{array}{c}\text { Projected Savings on Labor } \\
\text { (PLN/year) }\end{array}$ \\
\hline 1 & 37,405 & $314,576.1$ \\
\hline 2 & 1169 & 0 \\
\hline 3 & 10,842 & 0 \\
\hline 4 & 176 & 0 \\
\hline 5 & 9973 & $106,411.9$ \\
\hline 6 & 392 & 3555.44 \\
\hline 7 & 78 & 1248 \\
\hline 8 & 3235 & $28,176.9$ \\
\hline 9 & 400 & 3484 \\
\hline 10 & 2664 & $29,064.2$ \\
\hline 11 & 36,226 & $524,190.2$ \\
\hline Total & 102,560 & $1,010,706.7$ \\
\hline
\end{tabular}

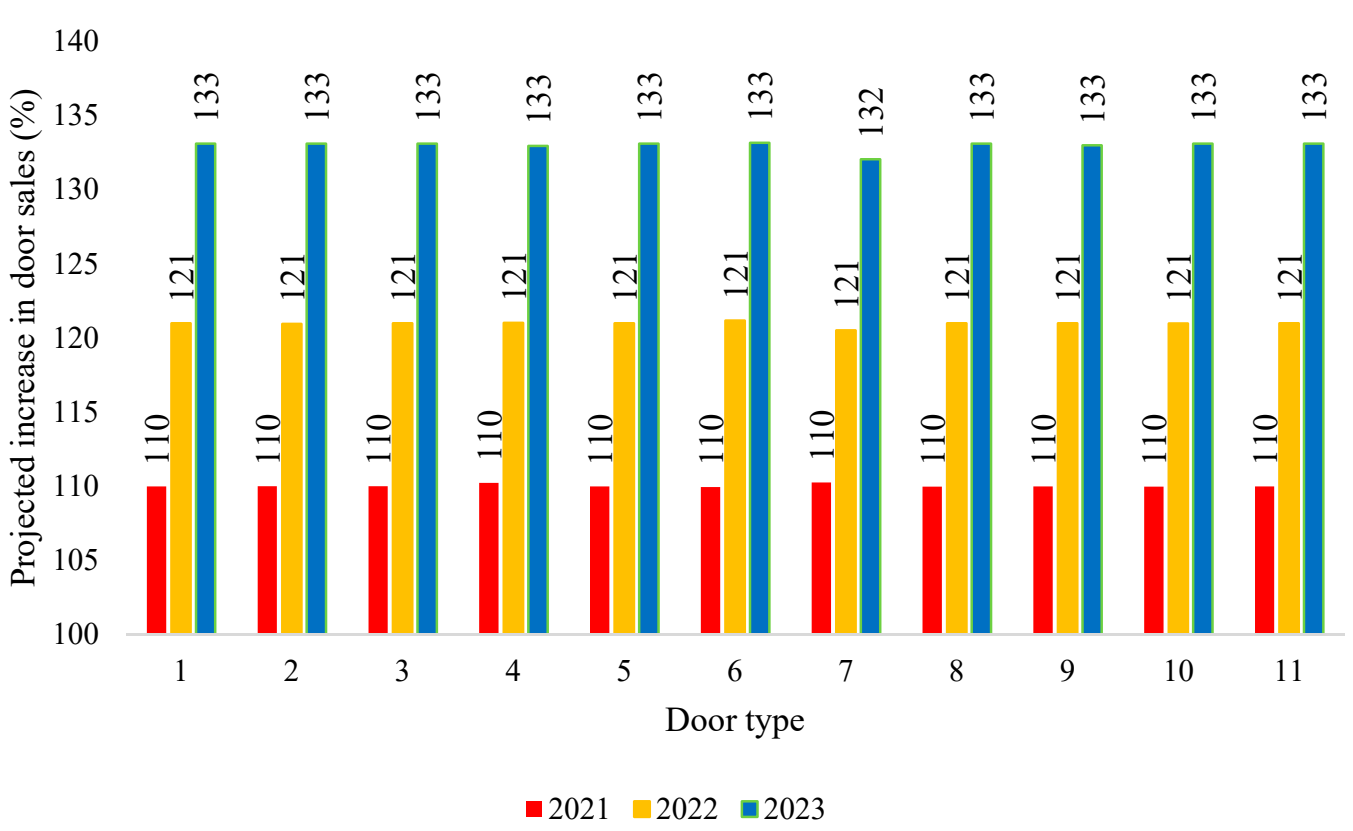

Figure 6. Projected percentage growth of door sales after innovation.

According to the company's projections, the highest sales are expected for type 1 doors, or interior entrance doors, and type 11 burglar-proof doors. The expected annual saving on each door unit is on par with these projections. The innovation introduced in the plant in the form of launching a mass customization line has an undoubted impact on the growing door sales trend in the years covered by the projection. The expected increase in sales of type 2-4 doors is not tantamount to generating savings, which results from the constant value of the TPC index for doors manufactured before and 
after the innovation. In the period covered by the projection, the labor savings are expected to increase continuously from about PLN 1 million in 2020 to nearly PLN 1.35 million in 2023. This confirms the economic justifiability of implementing innovations in the form of a customized production line.

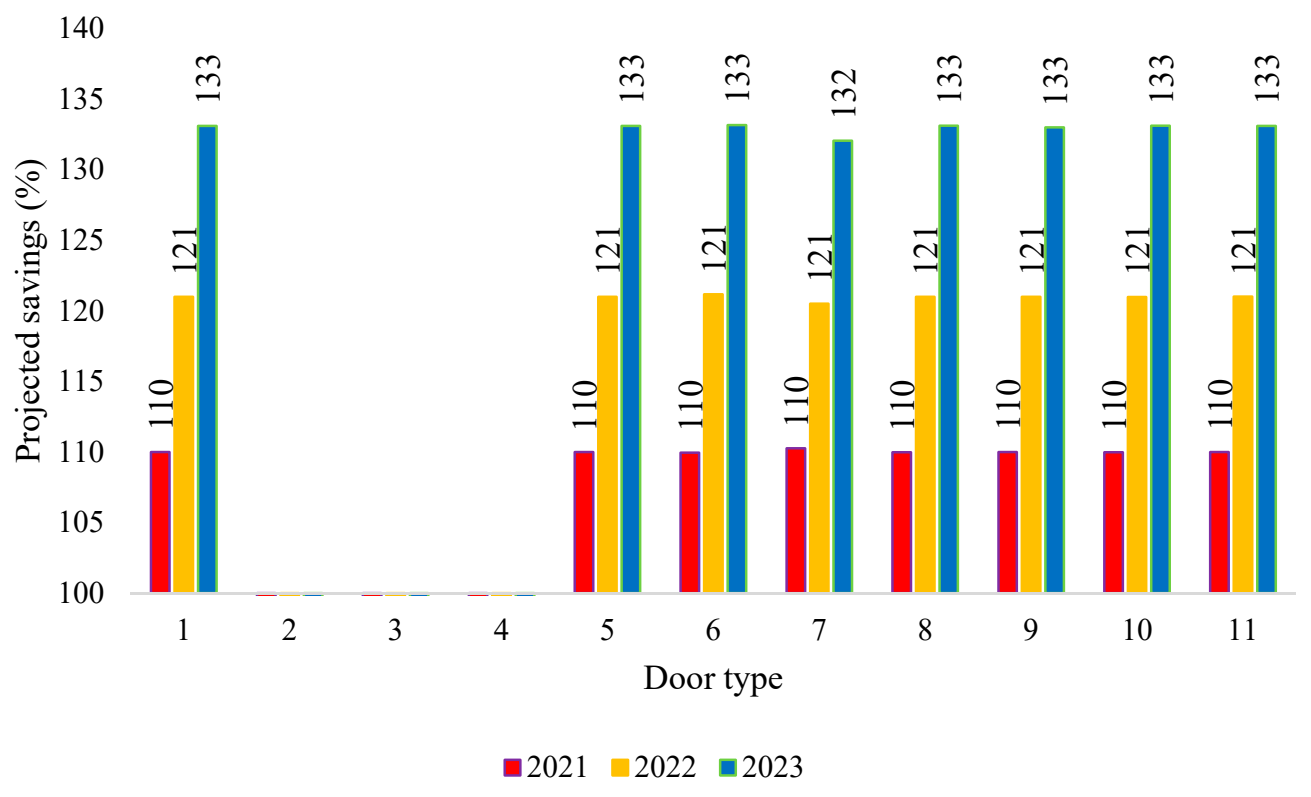

Figure 7. Projected percentage savings related to the reduction of the UCL.

\section{Discussion}

Over the years, customers' ability to customize the appearance and characteristics of products when making purchasing decisions has become a key factor in maintaining and increasing the competitiveness of manufacturing companies in various industries. Mass customization is presented as a marketing concept enabling the acquisition of a significant number of consumers while providing the opportunity to personalize the product to meet customers' expectations. Examples of such activities are visible in many sectors, such as automotive, electronics, fashion, cosmetics, food, as well as construction, architecture, and furniture [31-37]. This is why attempts at adapting systems to this concept are so important [38,39].

The analysis of economic and technical indexes taking into account the unit material and labor costs formed the basis for the evaluation of the profitability of the introduction of the mass customization concept in the door production plant. According to the company's forecasts for 2020-2023, the implementation of the concept using the TechnoPORTA line will result in a significant increase in sales of the entire analyzed range of products. An aspect that determines the introduction of the MC concept is also the anticipated savings result from the reduction of labor costs, to more than PLN 1 million per year. The annual technical production cost decreased by a maximum of $6 \%$, and for the types of doors with the highest expected number of sales, i.e., internal entrance doors and burglar-proof doors, by $4 \%$. There were no negative economic effects obtained in the area of analyzed indicators.

The implementation of $\mathrm{MC}$ refers to the trend of growing interest in the consumer real estate market and is associated with visible interest in the field of furnishing and even interior design. Therefore, MC can help the company Porta KMI Poland to strengthen its competitive advantage on domestic and foreign markets.

Due to the multitude of factors influencing the final level of costs incurred by the company, it would be necessary to extend the scope of research towards balancing the costs and benefits resulting from mass production of a non-standard structure of individual products in order to determine the optimum degree of their adjustment. The continuation of the research should consist in analyzing 
the missing links in the profitability of the MC process, such as electricity and heat consumption, quantitative efficiency, as well as the times of possible machine retooling and production tasks. Only by comparing the results of an analysis of all these factors will it be possible to clearly determine the profitability of the introduction of the MC concept and the savings achieved in this way. Such an analysis will also show whether MC is directed towards sustainable production in the economic, social and environmental sectors, which can be achieved through the optimal use of resources such as production materials, water, and electricity.

An unquestionable advantage of the introduction of MC by the company is the possibility of directing it towards the dynamically developing Industry 4.0. Linking a properly designed production line closely with IT systems may be the basis for increasing efficiency and flexibility of production, and in the future, having a technological line in which all devices communicate with one another, creating a smart production system [40-42].

Internal adverse factors of companies are those connected with production, technologies, and logistics. Mass customization requires a highly flexible production technology that can be expensive and time-consuming. Moreover, some processes are more flexible and are easier to be digitized than others, creating a serious gap in manufacturing operations. Mass customization also requires a strong direct-to-customer logistics system, which can be a weak point in the distribution process of the company [15].

\section{Conclusions}

On the basis of the analysis of technical and economic indexes, it can be concluded that the introduction of the concept of mass customization will reduce gross costs of each manufactured product, which will bring profits of significant importance in terms of annual sales. The production of each of the analyzed types of doors will not require additional costs and in many cases will significantly reduce them. The unit material cost of all types of doors after the introduction of innovation remains unchanged. The reason behind this is its value determined by the costs of materials used in the production of doors as well as their thickness. The highest value of the UMC index-450.4 PLN/pc recorded for type 2 doors, i.e., Aqua, is the result of expensive materials used in the construction of this type of door. Similarly, the lowest unit material costs were obtained for doors with simple constructions using cheaper materials (CPL and PVC veneer), i.e., type 4-121.2 PLN/pc and type 3-123 PLN/pc. For 8 of the 11 door types, the UCL index decreased, while for others it remains unchanged. The change in the absolute value of the TPC index is influenced by the UCL index, as it is a variable factor after the introduction of innovation. The TPC reduction savings result from the absolute values of TPC and UCL as well as UMC as a component of the total value of TPC. The highest percentage of TPC reduction was found for door types $7-6 \%$, and $5-5 \%$.

The value of labor costs and sales forecasts of 102,560 pieces results in forecast savings of more than PLN 1 million in 2020. Approximately 83\% of this amount concerns burglar-proof doors and internal entrance doors.

The production of each of the types of doors analyzed will not require additional costs and in many cases will significantly reduce them. The savings index in relation to the TPC before customization reaches even $6 \%$ for acoustic doors. It should be remembered, however, that the changes introduced, despite the fact that they will generate significant savings, are also connected with the reorganization of the production process and the employees, including production personnel, obtaining additional competences and the ability to analyze the flow of products and respond to any unscheduled deviations.

The introduction of the MC concept will allow the satisfaction of many individual customers at relatively low costs compared to traditional methods of customization of individual products. With growing customer demands and the changing heterogeneity of demand, mass customization will play an increasingly important role in the door industry while maintaining short project implementation times, with products not significantly different from those in the standard offer. 
Author Contributions: Conceptualization, M.P., J.B., T.R. and J.S.; methodology, M.P. and T.R.; software, M.P.; validation, M.P.; formal analysis, T.R. and J.S.; investigation, M.P., Z.K., T.R. and J.S.; resources, Z.K.; data curation, M.P. and Z.K.; writing —original draft, J.B. and M.P.; writing—review \& editing, J.B., T.R. and J.S.; visualization, M.P., J.B. and J.S.; supervision, T.R. and J.S.; project administration, Z.K.; funding acquisition, Z.K. and T.R. All authors have read and agreed to the published version of the manuscript.

Funding: This research was supported by the Ministry of Science and Higher Education's program 'Regional Initiative of Excellence' in the years 2019-2022, Project No. 005/RID/2018/19. The results of development work come from the project entitled "TechnoPORTA. Smart customized production line for the automated manufacture of technical doors", co-financed within the Operational Program Smart Development, Action 1.1. R\&D Projects of Enterprises', Sub-measure 1.1.2 'R\&D Work related to the Production of Pilot/Demonstration Systems.

Conflicts of Interest: The authors declare no conflict of interest.

\section{References}

1. Porter, M.E. Competitive Advantage: Creating and Sustaining Superior Performance; The Free Press: New York, NY, USA, 1985; pp. 1-4.

2. Barney, J. Looking inside competitive advantage. Acad. Manag. Exec. 1995, 17, 49-61. [CrossRef]

3. Day, G.S.; Wensley, R. Assessing advantage: A framework for diagnosing competitive superiority. J. Mark. 1988, 52, 1-20. [CrossRef]

4. Bednarz, J.; Bieliński, T.; Nikodemska-Wołowik, A.M.; Otukoya, A. Sources of the competitive advantage of family enterprises: An international approach focusing on China, Nigeria and Poland. EBER 2017, 5, 123-142. [CrossRef]

5. Wiechoczek, J. Koncepcja masowej kastomizacji w kreowaniu wartości dla nabywców produktów wybieralnych. Handel Wewnętrzny 2018, 4, 116-126.

6. Tseng, M.; Jiao, J. Mass customization. In Handbook of Industrial Engineering, 3rd ed.; Salvendy, G., Ed.; Willey \& Sons: New York, NY, USA, 2001; pp. 684-709.

7. Piller, F.T. Mass Customization, 3rd ed.; Gabler Verlag: Wiesbaden, Germany, 2003.

8. Andújar-Montoya, M.D.; Gilart-Iglesias, V.; Montoyo, A.; Marcos-Jorquera, D. A construction management framework for mass customisation in traditional construction. Sustainability 2015, 7, 5182-5210. [CrossRef]

9. Davis, S.M. Future Perfect, 1st ed.; Addison-Wesley: Reading, MA, USA, 1987; p. 148.

10. Pine, B.J. Making mass customization happen: Strategies for the new competitive realities. Plan. Rev. 1993, 21, 23-24. [CrossRef]

11. Pine, B.J. Challenges to Total Quality Management in Manufacturing. In Quality 1995 Yearbook; Cortada, J.W., Woods, J.A., Eds.; McGraw-Hill: New York, NY, USA, 1995; pp. 69-75.

12. Piller, F.T. Mass customization: Reflections on the state of the concept. Int. J. Flex. Manuf. Syst. 2004, 16, 313-334. [CrossRef]

13. Ferguson, S.M.; Olewnik, A.T.; Cormier, P. A review of mass customization across marketing, engineering and distribution domains toward development of a process framework. Res. Eng. Des. 2014, 25, 11-30. [CrossRef]

14. Squire, B.; Brown, S.; Readman, J.; Bessant, J. The impact of mass customization on manufacturing trade-offs. Prod. Oper. Manag. 2006, 15, 10-21. [CrossRef]

15. Zipkin, P. The limits of mass customization. Sloan Manag. Rev. 2001, 42, 81-87.

16. Arora, N.; Dreze, X.; Ghose, A.; Hess, J.D.; Iyengar, R.; Jing, B.; Joshi, Y.; Kumar, V.; Lurie, N.; Sajeesh, S.; et al. Putting one-to-one marketing to work: Personalization, customization, and choice. Mark. Lett. 2008, 19, 305-321. [CrossRef]

17. Toffler, A. The Third Wave; William Collins Sons \& Co. Ltd.: New York, NY, USA, 1980.

18. Ziemba, E.; Eisenbardt, M. Prosumers' participation in business processes. Online J. Appl. Knowl. Manag. 2015, 3, 114-127.

19. Dusi, D. Investigating the exploitative and empowering potential of the prosumption phenomenon. Sociol. Compass. 2017, 11, 1-11. [CrossRef]

20. Bardkci, A.; Whitelock, J. Mass-customisation in marketing: The consumer perspective. J. Consum. Mark. 2003, 20, 463-479. [CrossRef]

21. Piller, F.T.; Müller, M. A new marketing approach to mass customisation. Int. J. Comput. Integ. Manuf. 2004, 17, 583-593. [CrossRef] 
22. Nikodemska-Wołowik, A.M.; Bednarz, J.; Foreman, J.R. Trends in young consumers' behaviour-Implications for family enterprises. Econ. Sociol. 2019, 12, 11-24. [CrossRef]

23. Kasriel-Alexander, D. Top 10 Global Consumer Trends for 2017. Euromonitor International 2017. Available online: https://go.euromonitor.com/white-paper-2017-top-10-global-consumer-trends-EN.html (accessed on 31 January 2020).

24. Salesforce Research, Connected Shoppers Report, 3rd ed. 2019. Available online: https://www.salesforce.com/ content/dam/web/en_us/www/documents/datasheets/connectedshopperresearchreport.pdf (accessed on 31 January 2020).

25. Lihra, T.; Buehlmann, U.; Beauregard, R. Mass customization of wood furniture as a competitive strategy. Int. J. Mass Cust. 2008, 2, 200-215. [CrossRef]

26. Dimkow, S. Production system concept for implementing mass customization strategy in furniture industry. Int. J. Ind. Eng. Manag. 2012, 3, 185-194.

27. Schuler, A.; Buehlmann, U. Identifying Future Competitive Business Strategies for the US Residential Wood Furniture Industry: Benchmarking and Paradigm Shifts; USDA Forest Service General Technical Report GTR NE-304; USDA Forest Service: Newtown Square, PA, USA, 2003; p. 15.

28. EC. Summer 2019 Economic Forecast-Germany. July 2019. Available online: https://ec.europa.eu/info/sites/ info/files/economy-finance/ecfin_forecast_summer_10_07_19_de_en.pdf (accessed on 2 March 2020).

29. Moreira, M.P.; Lihra, T.; D'Amours, S.; Beauregard, R. Implementation of mass customization in a furniture manufacturing plant: The case of Shermag Inc. Cirrelt 2008, 03, 1-15.

30. Shults, D. Mass customization. The next big thing? Competing in a commodity world ... the business perspective of mass customization. Wood Dig. 2006, 1, 18-23.

31. Suzić, N.; Stevanov, B.; Ćosić, I.; Anisić, Z.; Sremcev, N. Customizing products through application of group technology: A case study of furniture manufacturing. Stroj. Vestin J. Mech. E 2012, 58, 724-731. [CrossRef]

32. Suzić, N.; Anisić, Z.; Forza, C. Introducing mass customization to SMEs in furniture industry: A case study. In Proceedings of the 7th World Conference on Mass Customization, Personalization, and Co-Creation (MCPC 2014), Aalborg, Denmark, 4-7 February 2014; Springer International Publishing: Cham, Switzerland, 2014; pp. 287-300.

33. Rocha, C.G.; da Formoso, C.T.; Tzortzopoulos, P. Adopting product modularity in house building to support mass customisation. Sustainability 2015, 7, 4919-4937. [CrossRef]

34. Boychenko, K.V. Mass customization in architecture. ISJ Theor. Appl. Sci. 2017, 2, 49-51. [CrossRef]

35. Piatkowski, A. Mass customization as a strategy of achieving a competitive advantage in the XXI century. Postępy Tech. Przetwórstwa Spożywczego 2017, 1, 147-155.

36. Barkova, N. Mass customization in the fashion industry. Vestn. Univ. 2018, 5, 85-90. [CrossRef]

37. Jost, P.J.; Susser, T. Company-customer interaction in mass customization. Int. J. Prod. Econ. 2020, 220. [CrossRef]

38. Da Silveira, G.; Borenstein, D.; Fogliatto, F.S. Mass customization: Literature review and research directions. Int. J. Prod. Econ. 2001, 72,1-13. [CrossRef]

39. Outón, J.L.; Villaverde, I.; Herrero, H.; Esnaola, U.; Sierra, B. Innovation mobile manipulator solution for modern flexible manufacturing processes. Sensors 2019, 19, 5414. [CrossRef]

40. Pilloni, V. How data will transform industrial processes: Crowdsensing, crowdsourcing and big data as pillars of industry 4.0. Future Internet 2018, 10, 24. [CrossRef]

41. Zhou, K.; Liu, T.; Zhou, L. Industry 4.0: Towards future industrial opportunities and challenges. In Proceedings of the IEEE 2015 12th International Conference on Fuzzy Systems and Knowledge Discovery (FSKD), Zhangiiajie, China, 15-17 August 2015; pp. 2147-2152. [CrossRef]

42. Iuorio, O.; Wallace, A.; Simpson, K. Prefabs in the north of England: Technological, environmental and social innovations. Sustainability 2019, 11, 3884. [CrossRef]

(C) 2020 by the authors. Licensee MDPI, Basel, Switzerland. This article is an open access article distributed under the terms and conditions of the Creative Commons Attribution (CC BY) license (http://creativecommons.org/licenses/by/4.0/). 